\title{
PENGARUH HARGA DAN KUALITAS INFORMASI TERHADAP PEMBELIAN IMPULSIF SECARA ONLINE
}

\author{
(Studi Kasus pada Mahasiswa Fakultas Ekonomi dan Bisnis Universitas \\ Teknologi Sumbawa)
}

\author{
${ }^{1}$ Puput Indarsih, ${ }^{2}$ Yandri Sudodo, ${ }^{3}$ Hanifa Sri Nuryani \\ ${ }^{1 *}$ Fakultas Ekonomi dan Bisnis Universitas Teknologi Sumbawa \\ 2Fakultas Ekonomi dan Bisnis Universitas Teknologi Sumbawa \\ ${ }^{3}$ Fakultas Ekonomi dan BisnisUniversitas Teknologi Sumbawa \\ Email: Indarsih28puput@gmail.com
}

\begin{abstract}
\begin{tabular}{ll}
\hline & Abstrak \\
\cline { 2 - 3 } Diterima & Penelitian ini bertujuan untuk mengetahui : I) Pengaruh Harga terhadap pembelian
\end{tabular}
Bulan juli 2019 Impulsif secara Online II) Pengaruh Kualitas informasi terhadap pembelian Impulsif secara Online III) Pengaruh Harga dan Kualitas informasi terhadap pembelian Impulsif secara Online. Model yang digunakan dalam analisis data yang di gunakan adalah uji

Diterbitkan

Bulan juli 2019

Keywords: Price,

Information

Quality, Impulsive

Purchasing instrumen penelitian, uji asumsi klasik, analisis regresi berganda, dan uji hipotesis. Alat analisis yang digunakan dalam penelitian ini adalah SPSS 16. Data yang digunakan yaitu data primer dan data sekunder dengan pengambilan sampel secara purposive sampling. Hasil penelitian menunjukkan bahwa I) Harga berpengaruh positif tetapi tidak signifikan yang ditunjukkan dengan nilai signifikansi sebesar 0,533 dimana nilai ini > 0,05. II) Kualitas informasi berpengaruh positif dan signifikan yang ditunjukkan dengan nilai signifikan sebesar 0,003 dimana nilai ini < 0,05. III) Harga dan Kualitas informasi secara simultan mempengaruhi pembelian impulsif sebesar 11,460.
\end{abstract}

\section{PENDAHULUAN}

Pesatnya perkembangan teknologi informasi termasuk internet membawa dampak yang besar bagi segala aspek, tidak terkecuali perkembangan dunia bisnis dan pemasaran. Sekarang sudah banyak orang yang memanfaatkan internet sebagai media bisnis dan pemasaran hal ini tidak aneh mengingat jumlah pengguna internet yang terus tumbuh JURNAL MANAJEMENDANEISNIS pesat dapat menjadi sebuah pasar yang potensial untuk dimasuki para pebisnis (Wijaya\& Kempa, 2018).

Internet sangat dibutuhkan dalam bertukar informasi dan berkomunikasi secara cepat tanpa ada batasan wilayah, ruang dan waktu. Internet dapat juga diimplementasikan dalam berbagai segi kehidupan, mulai dari bidang pemerintahan, pendidikan serta 
perdagangan. Apabila dikaitkan dengan perkembangan teknologi informasi maka media internet dapat menjadi pilihan dalam mendukung segala proses transaksi, salah satunya dalam transaksi perdagangan. Persaingan disektor perdagangan saat ini semakin ketat. Sehingga pelaku bisnis harus bisa memanfaatkan perkembangan teknologi internet agar dapat mempertahankan dan melanjutkan usahanya (Hidayat et al, 2013 ).

Menurut data dari APJII (Asosiasi penyelenggara jasa internet Indonesia) Jumlah pengguna internet tahun 2017 telah mencapai 143.26 juta jiwa atau setara dengan 54.68 persen dari total jumlah penduduk Indonesia. Data-data tersebut, disimpulkan bahwa lebih dari setengah jumlah penduduk Indonesia sudah mengenal dan menggunakan internet (Wijaya\& kempa, 2018).

Banyaknya pengguna internet di Indonesia dimanfaatkan berbagai pihak sebagai peluang untuk menjalankan usaha secara online. Dengan adanya media online, setiap orang bisa melaksanakan transaksi penjualan maupun pembelian kapanpun dan dimanapun. Munculnya media online sebagai media pemasaran menjadikan trend baru tersendiri bagi para konsumen sebagai media pemenuhan kebutuhan.Tidak hanya itu konsumen dalam hal ini dapat dengan mudah berinteraksi dengan situs penjual untuk mencari informasi, produk dan jasa yang benar-benar kita inginkan. Tanpa disadari, munculnya perkembangan media online ini telah merubah gaya hidup dan perilaku kita. Dahulu, kita harus pergi ke suatu tempat untuk mendapatkan produk yang kita inginkan. Sekarang, kita bisa memesan produk atau barang yang mau kita beli dengan bermodalkan smartphone yang kita miliki kapan saja dan dimana saja (Sudjadtmika 2017).

Menurut Ratna (2015) salah satu faktor penting konsumen tertarik untuk melakukan pembelian online, dapat dilihat berdasarkan faktor harga. Konsumen sekarang ini sangat sensitif terhadap harga suatu produk. Suatu produk akan lebih mudah diterima konsumen ketika harga dari produk tersebut bisa dijangkau oleh konsumen. Harga bisa diukur berdasarkan kesesuaian harga dengan kualitas produk, daya saing harga, dan kesesuaian harga dengan manfaat yang diberikan produk.

Menurut Wardoyo \& Andini (2017) Selain harga kualitas informasi melekat kepada produk atau jasa yang dijual. Informasi yang lengkap dan jujur merupakan hal yang sangat penting dalam melakukan pembelian dan penjualan secara online karena antara penjual dan pembeli tidak saling bertemu dan barang yang diperdagangkan pun hanya bisa dilihat melalui gambar sehingga kualitas barangpun agak sulit untuk diprediksi apakah sesuai dengan keinginan pembeli. Semakin baik kualitas informasi yang diberikan akan menambah minat pembeli untuk melakukan pembelian secara online.

Harga dan Kualitas informasi sangat mempengaruhi dalam keputusan pembelian secara online, dimana pembelian online yang dirasa lebih murah oleh konsumen dari pada pembelian secara langsung. Selanjutnya kualitas informasi yang relevan dan akurat dapat meyakinkan pelanngan terhadap produk yang di pasarkan secara online. Teknologi informasi memberi kemudahan pada konsumen dalam melakukan pembelian secara online. 
Munculnya fasilitas kemudahan dalam transaksi secara Online dalam berbagai aplikasi ini menimbulkan beberapa dampak negatif, diantaranya timbul keinginan berlebih dari para konsumen dalam melakukan transaksi secara online. Terkadang transaksi secara online ini terjadi tanpa ada rencana sebelumnya atau biasa yang disebut dengan pembelian impulsif (Miranda 2016).

Menurut Dewi permata et al (2014) Konsumen dengan karakter pembelian impulsif adalah konsumen yang tidak merencanakan sesuatu dalam berbelanja. Konsumen melakukan pembelian impulsif tidak terpikir untuk membeli suatu produk dan merek tertentu. Mereka langsung melakukan pembelian karena ketertarikan pada merek dan produk saat itu juga.Konsumen ini cenderung membeli secara spontan, tiba-tiba dan otomatis.

Pembelian impulsif tidak terjadi pada orang dewasa saja. Pasalnya teknologi canggih ini pun berdampak pada remaja, khususnya dalam penelitian ini Mahasiswa Fakultas Ekonomi dan Bisnis Universitas Teknologi Sumbawa. Mahasiswa salah satu yang berpotensi aktif dalam menggunakan situs jejaring sosial. Karena usianya yang terbilang masih muda dan mempunyai kecenderungan perilaku pembelian impulsif lebih besar. Mahasiswa dengan beragam karakteristik dan cara berpenampilan yang berbeda-beda. Cara berpenampilan mereka menciptakan gaya berbusana sehari-hari pun memang beragam. Hal demikian dapat dilihat dari ketertarikan mereka terhadap dunia fashion sangat besar, dan bisa dipastikan bahwa mahasiswa Fakultas Ekonomi dan Bisnis mempunyai kegemaran berbelanja. Hal tersebut dikarenakan remaja masa kini dihadapkan pada pilihan gaya hidup yang kompleks. Remaja yang masih pada tahap pencarian identitas diri, jadi banyak meniru apa yang dilihat dan didengar melalui media, termasuk media sosial.

Sebagai seorang remaja banyak mahasiswa yang telah melakukan jual beli melalui situs aplikasi seperti shoope.com, lazada,bukalapak maupun dari sosial media seperti whatsAap, facebook, dan instagram. Sebagai mahasiswa yang selalu ingin mengikuti trend yang sedang berkembang, ia akan cenderung lebih konsumtif dan berpotensi untuk melakukan pembelian impulsif. Karena jika dilihat secara subjektif dalam hal fashion, mereka yang mengikuti trend akan lebih modis dalam berpakaian dan akan menggunakan produk yang sedang trend pada saat itu. Sehingga produk atau jasa yang ditawarkan dalam online ini pun juga semakin bervariasi mengikuti trend zaman. Oleh sebab itu mahasiswa akan cenderung untuk melakukan pembelian impulsif secara online. Berdasarkan fenomena yang terjadi pada saat ini dan latar belakang diatas peneliti tertarik untuk melakukan penelitian dengan judul "Pengaruh Harga dan Kualitas Informasi Terhadap Pembelian Impulsif Secara Online Pada Mahasiswa Fakultas Ekonomi dan Bisnis Universitas Teknologi Sumbawa"

\section{STUDI LITERATUR}

\subsection{Harga}

Menurut Indriyo Gitosudarmo (2014) Harga itu sebenarnya merupakan nilai, yang dinyatakan dalam satuan mata uang atau alat tukar, terhadap suatu barang tertentu. Dalam kenyataannya besar kecilnya nilai atau 
JURNAL MANAJEMEN DAN BISNIS VOL.2 N0.12019

harga itu tidak hanya ditentukan oleh faktor fisik saja yang diperhitungakan, akan tetapi faktor-faktor psikologis dan faktor-faktor lainberpengaruh pula terhadap harga. Dengan demikian dapatlah diartikan bahwa harga adalah sejumlah uang yang dibutuhkan untuk mendapatkan sejumlah barang beserta jasa-jasa tertentu atau kombinasi dari keduanya.

\subsubsection{Indikator Harga}

Adapun indikator yang di pilih dalam penelitian ini, menurut Kotler dan keller terjemahan Saladin (2008), ada empat indikator pada harga yaitu:

1) Keterjangkauan harga, konsumen bisa menjangkau harga yang telah ditetapkan oleh perusahaan. Produk biasanya ada beberapa jenis dalam satu merek harganya juga berbedabeda dari yang termurah dan yang termahal. Dengan ini para produsen harys dapat menetapkan harga yang akan dibeli oleh konsumen.

2) Kesesuaian harga dengan kualitas produk, harga sering dijadikan sebagai indikator kualitas bagi konsumen, konsumen akan sering memilih harga yang lebih tinggi diantara dua barang yang lainnya karena konsumen melihat adanya perbedaan kualitas. Apabila harga lebih tinggi maka konsumen cenderung beranggapan bahwa kualitasnya juga lebih baik.

3) Daya saing harga, konsumen sering membandingkan harga suatu produk dengan produk sejenis lainnya, dalam hal ini mahal murahnya suatu produk sangat dipertimbangkan oleh konsumen pada saat akan membeli produk tersebut.

4) Kesesuaian harga dengan manfaat produk, konsumen memutuskan membeli suatu produk jika manfaat yang dirasakan lebih besar atau sama dengan yang telah dikeluarkan untuk mendapatkanya. Jika konsumen merasakan manfaat produk lebih kecil dari uang yang dikeluarkan maka konsumen akan beranggapan bahwa produk tersebut mahal dan konsumen berpikir dua kali untuk melakukan pembelian ulang.

\subsection{Kualitas informasi}

2.2.1 Definisi Kualitas informasi

$$
\text { Menurut Maniah \& }
$$

Hamidin (2017) Kualitas informasi adalah terletak pada bagaimana informasi tersebut dirasakan dan digunakan oleh penggunanya. Bagaimana informasi yang ditampilkan dapat mempengaruhi para pengambil keputusan. Atribut-atribut kualitas informasi dapat digunakan sebagai tolak ukur untuk meningkatkan efektivitas sistem informasi dan untuk mengembangkan strategi kualitas informasi untuk semua organisasi.

\subsubsection{Dimensi kualitas informasi} menurut Maniah \& Hamidin (2017) sebagai berikut:

a) Akurat

Informasi harus bebas dari kesalahan-kesalahan dan tidak bias atau menyesatkan, dan harus jelas 
mencerminkan

maksudnya.

Ketidakkakuratan dapat terjadi karna sumber informasi mengalami gangguan atau kesengajaan sehingga merusak atau merubah data-data asli tersebut.

b) Objektivitas

Sejauh mana informasi tidak bias, berprasangka dan tidak memihak. Penerapan dimensi objektivitas tergantung pada jenis informasi.Misalnya tinggi bangunan. Objektivitas jenis informasi lainnya, seperti deskripsi produk, mungkin dipengaruhi oleh preferensi penyedia informasi.

c) Dapat dipercaya

Sejauh mana informasi diajak benar dan kredibel. Dapat dipercaya dapat dilihat sebagai akurasi yang diharapkan. Sedangkan akurasi mengacu pada presisi yang dapat diverifikasi dimana informasi tentang dunia nyata ditangkap oleh sistem informasi, dapat dipercaya mengacu pada informasi yang dipercaya tanpa memeriksanya. Dapat dipercaya adalah subyektif karna ada berbagai tingkat kehati hatian dan prosedur subjektif yang berbeda untuk memutuskan mana informasi yang dipercaya.

d) Reputasi

Sejauh mana informasi sangat dihargai dalam hal sumber atau konten.

\subsection{Pembelian Impulsif}

2.3.1 Definisi pembelian impulsif
Pembelian impulsif adalah suatu tindakan pembelian yang dibuat tanpa direncanakan sebelumnya atau keputusan pembelian yang datang secara spontan dari seorang konsumen. Konsumen langsung membuat keputusan tanpa melakukan pencarian informasi dan mempertimbangkan berbagai merek. Ini adalah proses pembelian yang benar-benar impulsif yang sangat kenal unsur emosionalnya (irawan, 2007).Adapun Proses pembelian impulsif:

1) Proses pembelian yang setengah impulsif adalah keinginan pembelian yang muncul karena melihat berbagai merek dalam suatu kategori. Jadi, ini adalah pembelian yang impulsif untuk kategori produk.

2) Proses pembelian impulsif murni adalah calon pembeli langsung mengarahkan pikirannya atau hendaknya kepada suatu merek tertentu dan kemudian melakukan pembelian secara cepat. Kebutuhan akan kategori produk tersebut mungkin timbul di bawah sadar. Tidak ada informasi yang dicari dan tidak ada merek lain yang dipertimbangkan.

2.3.2 Indikator pembelian impulsif

Adapaun indikator pembelian impulsif menurut Sugiharto dan Japrianto (2011):

1) Spontanitas pembelian pembelian ini tidak diharapkan dan memotivasi konsumen untuk membeli sekarang, sering sebagai respon terhadap stimulasivisual yang langsung ditempat penjualan.

2) Kekuatan Pembelian 
Mungkin ada motivasi untuk mengesampingkan semua yang lain dan bertindak dengan seketika.

3) Kegairahan dan Stimulasi

Desakan mendadak untuk membeli sering disertai dengan emosi yang dicirikan sebagai menggairahkan atau liar.

4) Ketidakpedulian akan akibat

Desakan untuk membeli dapat menjadi begitu sulit ditoloak sehingga akibat yang mungkinnegatif diabaikan.

\section{KERANGKA KONSEPTUAL DAN HIPOTESIS PENELITIAN}

Kerangka berfikir dalam penelitian ini dapat dikemukakan sebagai berikut: Pengaruh harga (X1) dan kualitas informasi (X2) terhadap pembelian impulsif (Y) secara online. Secara sistematis kerangka konseptual dalam penelitian ini dapat di lihat pada gambar berikut ;

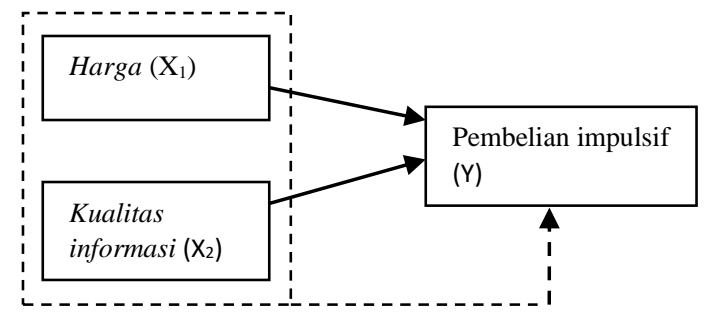

Gambar 2.1. Kerangka Konseptual

Keterangan :

$\longrightarrow$ : Pengaruh masing-masing

variabel independen terhadap dependen

------ : pengaruh variabel independen secara simultan terhadap variabel dependen

$$
\text { Berdasarkan pada Gambar }
$$

Kerangka Konseptual, maka penelitian ini mengacu pada pembelian impulsif yaitu sebagai variabel dependen, sedangkan variabel independen dalam penelitian adalah harga dan kualitas informasi. Penelitian ini dilakukakan untuk mengetahui pengaruh masing-masing variabel independen terhadap pembelian impulsif dan untuk mengetahui pengaruh kedua varibel independen secara bersama-sama terhadap pembelian impulsif.

\section{METODE PENELITIAN}

Penelitian ini adalah penelitian kuantitatif dengan survey sebagai metode pengumpulan data. Instrumen pengumpulan data adalah dengan menggunakan angket atau kuesioner. Untuk memperjelas masalah yang akan dibahas dan agar tidak terjadi pembahasan yang meluas atau menyimpang, maka perlu kiranya dibuat suatu batasan masalah. Adapun ruang lingkup permasalahan yang akan dibahas dalam penelitian ini yaitu penelitian ini dilakukan oleh Mahasiswa Fakultas Ekonomi dan Bisnis Universitas Teknologi Sumbawa yang beralamat di Jalan Raya Olat Maras, Dusun Batu Alang, kecamatan Moyo Hulu, Kabupaten Sumbawa, NTB.

\section{Teknik Analisis Data}

Metode analisis data yang digunakan dalam penelitian ini adalah menggunakan uji instrumen penelitian, uji asumsi klasik, uji analisis regresi linier berganda dan uji hipotesis. Interpretasi hasil penelitian baik secara parsial melalui uji-t maupun secara simultan melalui uji-F. Alat analisis yang digunakan SPSS 16.

\section{HASIL DAN PEMBAHASAN}

\section{Hasil Uji Instrumen Penelitian}

\section{Uji Validitas}

Uji validitas dilakukan dengan membandingkan nilai $r_{\text {hitungdengan }} r_{\text {tabelapabila }} r_{\text {hitung }}$ 
lebih besar dari $r_{\text {tabel }}$ (pada taraf signifikansi 0.05), maka dapat dikatakan item kuesioner tersebut valid,

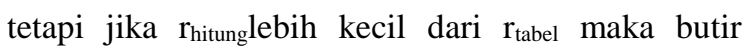
pernyataan tersebut tidak valid. Penelitian ini menghasilkan nilai $r_{\text {hitung }}>$ dari pada $r_{\text {tabel }}$ sebesar $0,885>0,361$ sehingga dapat disimpulkan bahwa semua instrumen dalam penelitian ini dapat dikatakan valid.

\section{Uji Reliabilitas}

Pengujian reliabilitas terhadap seluruh item atau pernyataan pada penelitian ini menggunakan rumus koefisien Cronbach Alpha. Nilai Cronbach Alpha pada penelitian ini akan digunakan nilai 0,60 dengan asumsi bahwa daftar pernyataan yang di uji akan di katakan reliabel bila nilai Cronbach Alpha $\geq$ 0,6.0 Masing-masing variabel dalam Penelitian ini menghasilkan nilai Cronbach Alpha yang lebih besar dari 0,60 dimana nilainya sebesar 0,830> 0,60. Kondisi ini menunjukan bahwa seluruh variabel tersebut adalah reliabel dan dapat digunakan pada analisis selanjutnya.

\section{Hasil Uji Asumsi Klasik}

\section{Uji Normalitas}

Uji normalitas pada penelitian ini menggunakan Kolmogorov Smirnov(K-S). Dalam uji ini apabila nilai sig $<0,05$ maka data tidak terdistribusi dengan normal. Namun jika nilai sig > 0,05 maka data terdistribusi dengan normal. Hasil uji normalitas yang menggunakan metode Kolmogorov-Smirnov di dapatkan hasil signifikansi dari uji normalitas sebesar 0,118 dimana hasil tersebut lebih besar dari taraf signifikansi 0.05, sehingga dapat disimpulkan bahwa uji normalitas pada penelitian ini adalah terdistribusi normal.

\section{Uji Multikolinearitas}

Ada tidaknya multikolinearitas dapat dilihat dari besarnya Variance Infalation Factor (VIF) dan nila Tolerance. Yaitu jika tolerance value $\leq 0.10$ atau VIF $\geq 0.10$ maka tidak terjadi multikolinearitas. dari hasil uji multikolinearitas yang dilakukan dalam penelitian menunjukan bahwa variabel harga (X1) dengan nilai tolerance $0.523>0.10$ dan nilai VIF $1.912<10$, variabel kualitas informasi (X2) dengan nilai tolerance $0.523>0.10$ dan nilai VIF $1.912<10$. Maka dapat disimpulkan bahwa semua variabel bebas tidak terjadi multikolinearitas.

\section{Uji Heteroskedastisitas}

Berdasarkan hasil uji gelejser di peroleh nilai probabilitas sebesar $0.5822>$ alpha 0.05, maka dapat disimpulkan tidak terjadi heterokedastisitas.

\section{Hasil Uji Analisis Regresi Linier Berganda}

Analisis regresi linier berganda digunakan untuk mengetahui pengaruh harga $\left(\mathrm{X}_{1}\right)$ dan kualitas informasi $\left(\mathrm{X}_{2}\right)$ secara bersama-sama terhadap pembelian impulsif (Y).

1) Nilai konstanta 6,500 menunjukkan ketika tidak terdapat harga dan kualitas informasi $\left(\mathrm{X}_{1}\right.$ $\mathrm{X}_{2}=0$ ) maka pembelian impulsif (Y) akan terjadi sebesar 6,500.

2) Koefisien regresi dari variabel Harga sebesar 0,153dan bertanda positif artinya untuk setiap peningkatan variabel $\mathrm{X}_{1}$ sebanyak $1 \%$, maka akan meningkatkan variabel Y sebesar $0,153 \%$ dengan asumsi variabel lain tetap.

3) Koefisien regresi dari variabel kualitas informasi sebesar 0,645 dan bertanda positif artinya untuk setiap peningkatan variabel $\mathrm{X}_{2}$ sebanyak $1 \%$, maka akan meningkatkan variabel $\mathrm{Y}$ sebesar $0,645 \%$ dengan asumsi variabel lain tetap 


\section{Hasil Uji Hipotesis}

1. Uji t (Uji Parsial)

Uji $\mathrm{t}$ dalam penelitian ini menggunakan tingkat signifikansi 0.05, jika nilai sig > 0.05 maka Ho ditolak dan Ha diterima, sedangkan jika nilai sig $<0,05$ maka Ho diterima dan Ha ditolak.

Hipotesis 1: Harga Berpengaruh Positif dan tidak signifikan Terhadap Keputusan Pembelian.

Berdasarkan hasil uji t dapat dilihat bahwa nilai $t_{\text {hitung }}$ variabel harga sebesar 0.595 , dimana $\mathrm{t}_{\text {hitung }}<\mathrm{t}_{\text {tabel }}(0,595<1.991)$ dengan nilai signifikansi $0.553>0.05$. Maka Ho diterima dan Ha ditolak, sehingga dapat di simpulkan bahwa terdapat hubungan positif dan tidak signifikan antara harga dengan pembelian impulsif

Hipotesis 2: Kualitas informasi Berpengaruh Positif dan signifikanTerhadap Keputusan Pembelian.

Berdasarkan hasil uji t dapat dilihat bahwa nilai $t_{\text {hitung }}$ variabel harga sebesar 3,024 dimana $t_{\text {hitung }}$ $>t_{\text {tabel }}(3,024>1.991)$ dengan nilai signifikansi $0.000<0.05$. Maka Ho ditolak dan Ha diterima, sehingga dapat di simpulkan bahwa terdapat hubungan positif tetapi dan signifikan antara kualitas informasi dengan pembelian impulsif.

\section{Uji F (Uji Simultan)}

Berdasarkan hasil uji $\mathrm{F}$ dapat dilihat bahwa nilai $\mathrm{F}_{\text {hitung }}>\mathrm{F}_{\text {tabel }}(11,460>3,10)$ dengan nilai signifikansi $0.000<0.05$, maka dapat disimpulkan bahwa terdapat pengaruh positif dan signifikan secara bersama-sama antara harga (X1), dan kualitas informasi (X2), terhadap pembelian impulsif (Y)

\section{Koefisien Determinasi $\left(\mathrm{R}^{2}\right)$}

dengan nilai $\mathrm{R}$ square adalah 0,209. Hasil ini menunjukkan bahwa pengaruh harga dan kualitas informasi terhadap pembelian impulsif secara online sebesar 20,9\% dan sisanya 79,1\% dipengaruhi oleh variabel lain yang tidak termasuk dalam penelitian.

\section{PEMBAHASAN}

\section{Pengaruh Kualitasharga terhadap pembelian impulsif secara online}

Hasil penelitian mendukung hipotesis pertama bahwa variabel harga berpengaruh positif dan tidak signifikan terhadap pembelian impulsif secara online pada Mahasiswa Fakultas Ekonomi dan Bisnis Universitas Teknologi Sumbawa. Hal ini dapat dibuktikan dengan nilai koefisien regresi $\mathrm{X}_{1}$ sebesar 0,153dan bertanda positif menyatakan bahwa setiap peningkatan harga sebesar 1\% akan meningkatkan pembelian impulsif secara onlinesebesar 0,153\% Berdasarkan hasil analisis data diperoleh nilai thitung variabel harga $\left(\mathrm{X}_{1}\right)$ sebesar 0,595 lebih kecil dari $\mathrm{t}_{\text {tabel }} 1,991$ dengan nilai signifikansi sebesar 0.553lebih besar dari 0,05, maka dapat dinyatakan bahwa harga tidak berpengaruh secara signifikan terhadap pembelian impulsif.

Berdasrakan hasil penelitian telah dibuktikan bahwa dari 4 pernyataan yang terdapat di harga berikut ini 3 pernyataan yang memiliki pengaruh yang paling besar terhadap pembelian impulsif secara online yaitu, kesesuaian harga dengan manfaat produk (P4) yaitu harga sesuai dengan manfaat produk yang diperoleh maka konsumen tertarik melakukan pembelian selanjutnya secara online. Selanjutnya (P2) kesesuain harga dengan kualitas produk yaitu harga yang ditawarkan sesuai dengan kualitas produk dalam jual beli onlinekonsumen tertarik untuk membeli secara online. Yang terakhir yaitu keterjangkaun harga produk (P1) yaitu apabila harga produk yang ditawarkan dalam jual beli online terjangkaun maka 
konsumen tertarik melakukan pembelian secara online.

Hasil penelitian ini mengidentifikasi bahwa harga berpengaruh positif dan tidak signifikan terhadap pembelian impulsif secara online.Hal ini berarti semakin tinggi pengaruh perubahan harga, misalnya perubahan harga yaitu, diskon harga dan beli satu gratis satu. maka semakin tinggi pula pembelian impulsif yang dilakukan oleh Mahasiswa Fakultas Ekonomi dan Bisnis Universitas Teknologi Sumbawa. Penelitian ini mendukung hasil penelitian yang dilakukan oleh Sudjatmika (2017).

\section{Pengaruh Kualitas informasi terhadap} pembelian impulsif secara online

Hasil penelitian mendukung hipotesis kedua bahwa variabel kualitas informasi berpengaruh positif dan signifikan terhadap pembelian impulsif secara online pada Mahasiswa Fakultas Ekonomi dan Bisnis Universitas Teknologi3. Sumbawa. Hal ini dapat dibuktikan dengan nilai koefisien regresi $\mathrm{X}_{1}$ sebesar 0,645 dan bertanda fositif menyatakan bahwa setiap peningkatan harga sebesar $1 \%$ akan meningkatkan pembeliam impulsif secara online sebesar 0,645\% Berdasarkan hasil analisis data diperoleh nilai $t_{\text {hitung }}$ variabel kualitas informasi $\left(\mathrm{X}_{2}\right)$ sebesar 3,024 lebih besar dari tabel 1,991 dengan nilai signifikansi sebesar 0.003lebih kecil dari 0,05, maka dapat dinyatakan bahwa kualitas informasi berpengaruh secara signifikan terhadap pembelian impulsif.

$$
\text { Berdasrakan hasil penelitian telah }
$$
dibuktikan bahwa dari 6 pernyataan yang terdapat di kualitas informasi berikut ini 3 pernyataan yang memiliki pengaruh yang paling besar terhadap pembelian impulsif secara online yaitu, yang pertama akurat (P2) yaitu apabila informasi diberikan secara akurat maka konsumen tertarik melakukan pembelian secara online. Selanjutnya tepat waktu (P3) yaitu informasi mengenai biaya pengiriman produk/barang yang ditawarkan melalui online disesuaikan dengan lokasi pembeli. Yang terakhir kelengkapan (P5) yaitu informasi spesifikasi produk dipaparkan secara terperinci konsumen tertarik melakukan pembelian secara online.

Hasil penelitian ini mengidentifikasi bahwa kualitas informasi berpengaruh positif dan signifikan terhadap pembelian impulsif secara online.Hal ini berarti semakin tinggi pengaruh kualitas informasi yang relevan, akurat, tepat waktu, dan kelengkapan maka semakin tinggi pula pembelian impulsif yang dilakukan oleh Mahasiswa Fakultas Ekonomi dan Bisnis Universitas Tekonologi Sumbawa.Penelitian ini mendukung hasil penelitian yang dilakukan oleh Wijaya dan Kempa (2018).

\section{Pengaruh Harga dan Kualitas informasi secara bersama-sama terhadap pembelian impulsif secara online}

Hasil penelitian mendukug hipotesis ketiga bahwa variabel harga dan kualitas informasi secara bersama-sama berpengaruh terhadap pembelian impulsif secara online pada Mahasiswa Fakultas Ekonomi dan Bisnis Universitas Teknologi Sumbawa. Hal ini dapat dibuktikan dengan nilai $f_{\text {hitung }} 11,460$ lebih besar dari $\mathrm{F}_{\text {tabel }} 3,10$ dengan nilai signifikan $0,000^{\mathrm{a}}$ lebih kecil dari 0,05, dapat disimpulkan bahwa harga dan kualitas informasi secara bersama-sama berpengaruh signifikan terhadap pembelian impulsif secara online pada Mahasiswa Fakultas Ekonomi dan Bisnis Universitas Teknologi Sumbawa.

Berdasrakan hasil penelitian telah dibuktikan bahwa dari 4 pernyataan yang terdapat di variabel harga berikut ini 3 
pernyataan yang memiliki pengaruh yang paling besar terhadap pembelian impulsif secara online yaitu, kesesuaian harga dengan manfaat produk (P4) selanjutnya (P2) kesesuain harga dengan kualitas produk . Yang terakhir yaitu keterjangkaun harga produk (P1). Dan hasil penelitian variabel kualitas informasi di buktikan bahwa dari 6 pernyataan yang terdapat di kualitas informasi berikut ini 3 pernyataan yang memiliki pengaruh yang paling besar terhadap pembelian impulsif secara online yaitu, yang pertama akurat (P2), selanjutnya tepat waktu (P3),yang terakhir kelengkapan (P5).

\section{PENUTUP}

\section{Kesimpulan}

Berdasarkan hasil analisis dan
pembahasan tentang pengaruh harga dan
kualitas informasi terhadap pembelian impulsif
secara online pada Mahasiswa Fakultas
Ekonomi dan Bisnis Universitas teknologi
Sumbawa. Maka dapat ditarik beberapa
kesimpulannya yaitu:

1) Harga berpengaruh positif dan tidak signifikan terhadap pembelian impulsif secara online. Hal ini berarti semakin tinggi pengaruhperubahan harga, misalnya perubahan harga yaitu, dengan adanya diskon harga dan beli satu gratis satu ,maka semakin tinggi pembelian impulsif yang dilakukan. Nilai koefisien $\mathrm{X}_{1}$ sebesar 0,153 dan bertanda fositif dan dengan nilai signifikansi sebesar 0.553lebih besar dari 0,05, maka dapat dinyatakan bahwa harga tidak berpengaruh secara signifikan terhadap pembelian impulsif secara online. Dengan demikian $\mathrm{H}_{1}$ ditolak.

2) Kualitas informasi berpengaruh positif dan signifikan terhadap pembelian impulsif JURNAL MANAJEMENDANBISNIS secara online. Hal ini berarti semakin tinggi pengaruh kualitas informasi yang relevan, akurat, tepat waktu, dan kelengkapa maka semakin tinggi pembelian impulsif yang dilakukan. Nilai koefisien $\mathrm{X}_{2}$ sebesar 0,645 dan bertanda positif dan dengan nilai signifikansi sebesar 0.003lebih kecil dari 0,05, maka dapat dinyatakan bahwa kualitas informasi berpengaruh secara signifikan terhadap pembelian impulsif secara online. Dengan demikian $\mathrm{H}_{2}$ diterima.

3) Harga dan Kualitas informasi secara bersama-sama berpengaruh terhadap pembelian impulsif secara online. Hasil ini dilihat dari nilai $F_{\text {hitung }}$ lebih besar dari $F_{\text {tabel }}$ Sebesar 11,460> 3,10 dengan nilai signifikansi $0,000<0,05$ artinya harga dan kualitas informasi secara bersama-sama berpengaruh terhadap pembelian impulsif secara. Dengan demikian $\mathrm{H}_{3}$ diterima.

\section{Saran}

1) Bagi penjual online shop

Untuk meningkatkan penjualan melalui pembelian impulsif. Sebaiknya pihak penjual online menetapkan harga dalam online yang sesuai standar dapat mudah terjangkau oleh mahasiswa, selain itu harga dalam online sesuai dengan kualitas barang yang didapat konsumen dan harga dalam online tidak jauh berbeda dari harga yang ditawarkan dari situssitus lain selain harga,sebaiknya sebagai pihak penjual online menetapkan kualitas informasi yang akurat, relevan tepat waktu dan kelengkapan.

2) Bagi konsumen

Bagi konsumen khususnya mahasiswa Fakultas Ekonomi dan Bisnis Universitas 
Teknologi Sumbawa, dalam mengkonsumsi atau berbelanja menggunakan media online sebaiknya tindakan mengonsumsi suatu barang atau jasa tidak hanya untuk memenuhi keinginan dan mengikuti trend demi kepuasan semata melainkan lihat juga faedah dari kegunaan produk tersebut sehingga perilaku konsumsi dapat sesuai yang disyariatkan oleh kepercayaan masing-masing yakni tidak berlebih-lebihan dalam membelanjakan hartanya.

3) Bagi akademik

Semoga penelitian ini dapat dijadikan bahan referensi dan dokumentasi sebagai bahan acuan dalam penelitian yang akan datang selain jurnal dan buku-buku yang sudah ada.

4) Bagi peneliti selanjutnya

Dalam penelitian ini tentu saja masih mengalami banyak sekali kekurangan, karena adanya keterbatasan dari peneliti, sehingga peneliti berikutnya diharapkan perlu menjelaskan secara lebih lengkap dengan menambah teori yang mendukungyaitu :Marketing Mix

\section{DAFTAR PUSTAKA}

Adhyta Wulan Gitaningmamba., (2013). Pengaruh Promosi PenjualanTerhadap Impulse Buying (Studi Kasus Pada Toko Lois JeansKota Kasablanka Periode Januari-Maret 2013)

APJII (Asosiasi Penyelenggara Jasa Internet Indonesia 2017), Penetrasi Perilaku Pengguna Internet

Indonesia (2017)
Ekawati ,W.N. (2016). Pengaruh E Jurnal Manajemen Universitas Udayana, 5(7). Pengaruh Promosi,

Atmosfer Gerai, dan Merchandise terhadap Pembelian Implusif Pada Hardy's Mall Gatsu Denpasar. Jurnal Manajemen Unud. $\quad$ 5(1), 4132-4160

Ghozali, Imam. (2011). “Aplikasi Analisis Multivariale dengan Program IBM SPSS 19.Semarang: Badan Penerbit Universitas Diponegoro

Hidayatet al. (2013).Informasi, K., Terhadap, P. E., Com, B., \&Priyono, A. A. (2013).Prodi manajemen, 64-78.

Irawan, H.D. (2007). Smarter Marketing Moves: Membangun Keunggulan Melalui Informasi Komunikasi, dan Produk. Jakarta :Gramedia

Indriantoro, Nur, \& Bambang Supomo (2009). Metodologi Penelitian bisnis untuk akuntansidan manajemen, Edisi pertama.Yogyakarta : BPFE Yogyakarta.

Japrianto, E., dan Sugiharto S., 2011, Pengaruh Shopping Life Style dan fashion Involvement terhadap Impulse Buying Behavior Masyarakat Surabaya, jurnal Manajemen Pemasaran, Vol. 6, No. 1, April: pp 32-41

Gitosudarmo, indriyo (2014) Manajemen pemasaran Edisi kedua.Yogyakarta BPFE Yogyakrta.

Kotler \&Keller.(2009). Manajemen Pemasaran.Jilid 1.Edisike 13 Jakarta: Erlangga.

Ma'aruff, H. (2006). Pemasaran Ritel. Jakarta: PT Gramedia Pustaka Utama. 
JURNAL MANAJEMEN DAN BISNIS VOL.2 NO.12019

Miranda, Y. C., \&Machung, U. (2016). Kajian Terhadap Faktor yang Memepengaruhi Impulsie Buying dalam Online Shopping.Jurnal Kompetensi, $10(1)$.

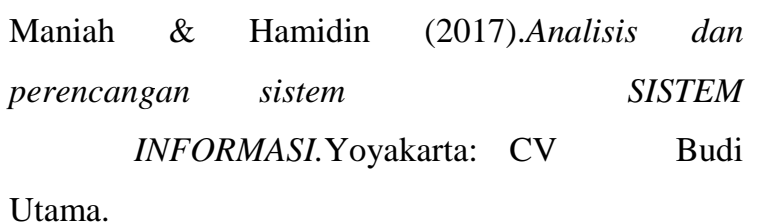

Nasution Hamni Fadillah Volume 4 Nomor 1 Ed. Januari - Juni 2018.

Pengaruh Kemudahan Dan Harga Terhadap Keputusan Pembelian Produk Pakaian Secara Online (Studi Kasus Mahasiswa Belanja Online Pada FEBI IAIN Padangsidimpuan)

Permata Dewi S, A.Widad, Dian Eka., Manajemen Bisnis dan Terapan (2014). $\quad$ Faktor-

Faktor Yang Mempengaruhi Pembelian Impulsif Pada Konsumen Butik di Palembang Trade Center Palembang

Ratna, D.I. (2015). Pengaruh harga dan kepercayaan terhadap keputusan pembelian secara online (studi kasus pada harapan maulina hijab Jombang).X(1).

Saladin, D. (2008). Manajemen Pemasaran Analisis, Perencanaan, Pelaksanaan, dan Pengendalian. Linda Karya, Bandung.

Sugiyono. (2014). Metode Penelitian bisnis pendekatan kuantitatif, kualitatif, dan $R \& D$. Bandung: Alfabeta.

Sugiyono, (2007).Statistik Untuk Penelitian. Bandung: Alfabeta
Sanusi, Anwar. (2012). Metodologi Penelitian Bisni.Jakarta : Salemba Empat

Sudjatmika Fransiska Vania Agora Vol. 5, No. 1, (2017).

Pengaruh Harga, Ulasan Produk, Kemudahan, Dan Keamanan

Terhadap Keputusan Pembelian Secara Online Di Tokopedia.Com.

Wijaya C, \& Sesiliya Kempa AGORA Vol. 6, No. 2 (2018). pengaruh kepercayaan, kemudahan, kualitas informasi terhadap kepuasan konsumen melalui keputusan pembelian produk fashiondi Lazada.

Wardoyo \& Intan Andini ., Ekonomi Manajemen Sumber Daya (2017) .

Faktor-Faktor yang berpengaruhi terhadap keputusan pembelian secara online pada Mahasiswa Universitas Gunadarma.

Dharmmesta, Basu Swastha Dan Handoko, T. Hani.

(2013). ManajemenPemasaran: Analisis Perilaku Konsumen. Yogyakarta: BPFE. akurat.peneliti menyarankan untuk 